following positive pressure ventilation initiated immediately after birth in infants with respiratory distress syndrome. Pediatr Pulmonol 9:244-250

22. Bose CL, Lawson EE, Greene A, Mentz W, Friedman M 1986 Measurement of cardiopulmonary function in ventilated neonates with respiratory distress syndrome using rebreathing methodology. Pediatr Res 20:316-320

23. Edberg KE, Sandberg K. Silberberg A, Sjöqvist BA, Ekström-Jodal B, Hjalmarson O 1991 A plethysmographic method for assessment of lung function in mechanically ventilated very low birth weight infants. Pediatr Res 30:50 I504

24. Edberg KE, Sandberg K, Silberberg A. Ekström-Jodal B, Hjalmarson O 1991
Lung volume, gas mixing, and mechanics of breathing in mechanically ventilated very low birth weight infants with idiopathic respiratory distress syndrome. Pediatr Res 30:496-500

25. Sandberg K, Sjöqvist BA, Hjalmarson O. Olsson T 1984 Analysis of alveolar ventilation in the newborn. Arch Dis Child 59:542-547

26. Sjöqvist BA, Sandberg K. Hjalmarson O. Olsson T 1986 Method for analysing multiple-breath nitrogen washouts. Med Biol Eng Comput 24:83-90

27. Fox WW. Schwartz JG, Shaffer TH 1979 Effects of endotracheal tube leaks on functional residual capacity determination in intubated neonates. Pediatr Res 13:60-64

\title{
Announcement
}

\section{Annual Meetings}

The American Pediatric Society, The Society for Pediatric Research, and The Ambulatory Pediatric Association will hold their annual meetings May 2-5, 1994 at the Washington State Convention and Trade Center, Seattle. For further information, contact APS/SPR Association Headquarters, 141 Northwest Point Blvd., P.O. Box 675, Elk Grove Village, IL 60009-0675, phone (708) 427-0205, fax (708) 427-1305 or Ambulatory Pediatric Association, 6728 Old McLean Village, McLean, VA 22101, phone (703) 556-9222, fax (703) 556-8729. 